\title{
Improving Language Pedagogy through Exploration of Learners' Errors: An Examination of Undergraduates' Written Communication
}

\author{
Fizza Farrukh* \\ Anmol Ahmad ${ }^{* *}$
}

\begin{abstract}
One major part of language learning pedagogy includes identifying and rectifying discrepancies while communicating through the target language. In such educational settings, the importance of understanding learners' errors becomes undeniable for both the pupil and pedagogue. Keeping this in forefront, the current investigation sampled twohundred and ten emails jotted down by ESL ('English as a Second Language') students to their teachers. This comparative investigation divided the learners' emails into two groups; First Semester and Fourth Semester, enrolled in MA English at COMSATS Institute of Information Technology, Virtual Campus, Islamabad. Utilizing Corder's Model (1967) and Sawalmeh's Categorization (2013), the emails were scrutinized and the results established that selected Pakistani learners commit nine different errors regularly in their electronic mail communiqué. Moreover, these outputs were comparatively studied utilizing the statistical software of SPSS (Version 16.0). These results highlighted a significant difference between the two semesters, which revealed a considerable reduction of errors in the learners' language use as they move from first to fourth semester of the prescribed degree program. Additionally, Richards' framework (1974) for deciphering source of learners' errors was employed, which depicted that the first semester students' first language (Urdu) frequently interferes when they use the second language (English) in writing emails. Meanwhile, the fourth semester students' language errors majorly contained deviant structures or ignorance of target language's (English) rules. Considering these
\end{abstract}

* Air University, Islamabad, Pakistan

** Air University, Islamabad, Pakistan 
findings, the study proposes similar studies to be conducted on other institutes' pupils and also recommends practical methodologies like corrective feedback for teachers, in aiding learners to fortify their command on English language.

Keywords: Language Learning Pedagogy, Written Communication, ESL, Email, Error Analysis.

\section{Introduction}

Students are learners, and as they are in the process of learning, they are bound to make slips while grasping the new concepts. A careful evaluation of such errors helps the teacher to designate efforts within that particular weak area of the student. For obtaining proficiency in English language, the learners are expected to gain expertise on four fundamental skills: reading, writing, listening and speaking. Particularly in the case of writing skills, the learners undergo many difficulties (Adas \& Bakir, 2013) as it has been considered challenging (Cole \& Feng, 2015). Experts also believe that writing is the skill in which majority of the students tend to build incorrect sentences initially. As stressed by AbiSamra (2003), Error Analysis is conducted on ESL learners' language and primarily focuses on the errors which learners make. Learning English as a second language means grasping the language at grammatical level, punctuation, orthography and phonology. So, in this sense, error analysis becomes a practical resource of information for the educators because the instructors can not only investigate students' errors but also improve the effectiveness of their teaching. According to Jabeen et al. (2015), error analysis aids in discovering such strategies which learners incorporate in order to ease the process of language learning; further on, it enables the teachers to track learners' errors; it also helps in obtaining apt information on common difficulties in language learning or on how to prepare relevant teaching materials. Correspondingly, Fang and Xue-mei (2007) state that such a methodical analysis of errors can be of immense worth to all those concerned and, particularly, to the teachers. 
Improving Language Pedagogy through Exploration of Learners' Errors

\section{Objectives}

The purpose of this study includes the following:

- To assess the errors committed by the CIIT Virtual Campus Undergraduate English students of First and Fourth Semester in their written emails.

- To define and categorize the types of errors committed by the students in their written emails.

- To compare and contrast the error of First Semester students and their sources with those of the Fourth Semester students.

\section{Literature Review}

Within the field of Error Analysis, an error is defined as creation of incorrect forms by non-native speaker of the language, while either speaking or writing, due to his/her deficient awareness of the rules of that target language (Khansir, 2012). According to Douglas Brown (1994), linguistic errors can be summed up as perceptible divergence from adult grammar of a native speaker, depicting the inter-language competency of the learner.

\section{Error Analysis}

The field of Error Analysis is involved in studying and analyzing the errors made particularly by the second language and foreign language learners (Khansir, 2012). It is generally concerned with the compilation, study and analysis of errors made by students (Corder, 1976). So it is a process of determining the incidence, nature of causes and consequences of unsuccessful language. In such a way, it can be classified as a method which can be used to decipher text or discoursebased errors.

\section{Origin of Error Analysis}

Error Analysis was initialized by Pit Corder in 1967. It was in his article entitled “The Significance of Learner's Errors” that error analysis came into limelight as a new subject. As mentioned by Khansir (2012), with the passage of time, Error Analysis developed as a new subdivision of applied linguistics by the year 1960 and it continued to progress and ultimately obtained extensive recognition by the year 1970 . 


\section{Significance of Error Analysis}

The primary importance of error analysis lies in the fact that it helps to identify type and pattern of error and also, the error taxonomies. Therefore, Error analysis becomes valuable because it explains difficulties that might be faced by the students while learning the target language.

Such analyses are positive both for students and teachers as well as for the curriculum designers and schoolbook writers, because it shows them a student's progress and aids them in molding their manuals accordingly. They can show researchers what new strategies can be adopted to aid the learners in learning a second language and also indicate the type of errors learners make.

\section{Previous Studies in the Field of Error Analysis}

Numerous researches have been conducted within this field of Error Analysis through various perspectives. Jayasundra and Premarathna (2011) conducted a linguistic analysis of written compositions of undergraduates belonging to Sri Lanka. The study determined grammar to be the largest category in which the students committed errors. However, this study had limited eight basic categories and offered no comparative analysis for a better assessment of the students.

Another interesting study conducted within the field of Error Analysis was by Mungungu (2010) on the writings of Namibian Learners. Mungungu concluded after his analysis that the students of Namibia committed majority of the errors in prepositions, articles and spellings. This study was solely based on one class and did not compare the results with any other class, in order to make the results more generalizable.

Nzama (2010) conducted an interesting study by comparing the errors committed by students belonging to urban and rural schools. This comparative study helped to generalize the results. It also helped in answering the fact that whether the errors committed by urban school students and rural school students are the same or different. However, the main purpose of Nzama (2010) in this research was to find out the reason for lack of comprehension of English and he concluded that lack of reading material, libraries and a lack of proper professional training of the teachers proves to be a hindrance in understanding English among the learners.

In the context of Saudi Arabia, Sawalmeh (2013) conducted a study 
on the students' writings who were studying in the preparatory (initial semester) program of the college. This study concluded that ten basic errors were committed by the Saudi Learners, which included errors of verb tense, word order, sentence fragments etc. This particular study had a well-defined framework and methodology, which guided the current study immensely so that it could be performed within the Pakistani context. However, this study by Sawalmeh (2013) did not utilize comparative analysis to make the findings more generalizable. Nevertheless, it gives a good idea of the errors committed by the learners in Saudi Arabia.

\section{Virtual Communication between Students and Teachers}

In the environment of Virtual teaching, the faculty uses various communication tools such as announcements, discussion board, and forums in order to communicate with the students (JISC, 2004). This interaction aids the faculty member to show to students that he/she cares about who they are, vigilantly replies their queries and concerns, and is available to do the mentoring that is needed. In such a scenario, the feedback plays a major role in conveying the point-of-view of the students. This feedback is generally conveyed by the medium of Email, forming a connection between students and teachers, so that they can discuss the course contents and problems. According to JISC (2004), the emails of the students reveal their written practices because students email to their tutors and ask the questions and take help. So these written practices can easily serve as useful data to assess their use of English because ultimately it is the language of communication on email. According to Ulijn and Strother (1995: 153), writing is an active and productive skill. Furthermore, when it comes to using language, in special perspective of emails, the importance of writing further increases but to make this writing more effective it should be error-free. This state can be obtained through the use of Error Analysis (also termed as 'EA' in short). By this, we can obtain a complete spectrum of ratios of different types of errors.

\section{Methodology}

The study was a mixed method research, qualitative and quantitative. The study was descriptive in nature where observations were made after analyzing the general emails of the students of COMSATS Institute of 
Information Technology (Virtual Campus) under the practical guidance of the framework. In such a scenario, content analysis of the emails was the sole research method for analyzing the errors of the students of first and fourth semester students of Fall Session 2014. The data collected were tabulated, analyzed and interpreted in the light of the objectives of the study. On the basis of these observations, the qualitative analysis was quantified, categories were made and the research questions were answered. Statistical procedures of frequencies and percentage were used for analysis and presentation of data.

\section{Population}

According to Burns and Grove (1993), population includes all the elements (events, individuals, objects) that meet the sample criteria for inclusion in a study or consideration. Here in this research work the Teacher-Student Emails of COMSATS Institute of Information Technology (Virtual Campus) have been taken as population to be tested for the purpose.

\section{Sampling}

Criterion Sampling has been used in this study for selecting a set of emails. While sampling, it was ensured there was a different sender of every email. This implied that every email must have a different author. This criterion yielded 105 emails received from first semester students and 105 emails received from fourth semester students. This made the data to consist of a total of 210 emails to be studied. Quantity of emails obtained from both semesters was attempted to be kept similar, for developing a uniform comparison. The emails were written by students in the Fall 2014 Semester (from the month of January to May 2014) belonging to the Undergraduate program of MA English being conducted at COMSATS Institute of Information Technology (Virtual Campus). The provided bio-data from the students was particularly studied to ensure that all the students belonged to Pakistan, in order to avoid any disorder in the process.

\section{Theoretical Framework}

This study utilized the framework and methodology provided by Corder's model for Error Analysis (1967) which has been replicated consistently since its arrival. A more clarified form of this model was 
formulated by Sawalmeh's categorization (2013), which served to guide the current research as well. According to both of these methodologies, the basic steps for conducting an Error Analysis include: (1) Collecting the samples of errors, (2) Identification of the errors within those collected samples, and (3) Description of the particular errors.

For investigation of sources of errors, Richards (1974) framework was employed. This framework suggests that the causes of learners' errors can be classified into the following categories:

(1) Inter-lingual Errors: These are caused by interference of the mother tongue or first language while using the second language in communication.

(2) Intra-lingual Errors: These appear as a result of incomplete knowledge of the learners. Within this category, the learners also tend to generalize some basic rules to every structure, causing overgeneralization.

\section{Collection of Data}

The emails referred by the students of MA English to their respective teachers were collected with the consent of the teachers. Out of this pool of emails, the emails were separated into two categories. The first category consisted of emails from first semester students, while the second category comprised of emails from fourth semester students. 105 emails were picked from both the categories and the information was prepared for analysis.

\section{Analysis of Data}

After a careful understanding of the identification marks provided for the errors by the framework, the researchers were able to analyze, identify, pick and categorize the errors out of every email. After the analysis, the quantified data containing frequencies was organized in the shape of tabular and graphical representation. This elaboration helped in interpreting the results. Thus, the merger of qualitative and quantitative methods helped in achieving a comprehendible outcome of the research.

\section{Results and Discussion}

After the application of the framework, the following errors were discovered in the emails: (1) Capitalization, (2) Word Order, (3) Subject- 
Verb Agreement, (4) Pronoun, (5) Spelling, (6) Verb Tense, (7) Preposition, (8) Article, and (9) Punctuation. The detailed analysis of all errors with each category has been discussed, individually:

\section{Capitalization Errors}

Within this category, students employ the use of the lower case letters (small case letters) instead of using the upper case letters (capital letters). These capitalization errors were committed 366 times by the First Semester Students, while they were committed 315 times by the Fourth Semester Students.

A comparative graphical evaluation (Figure 1) of findings from both semesters reveals that the capitalization errors reduce to a considerable amount in the fourth semester.

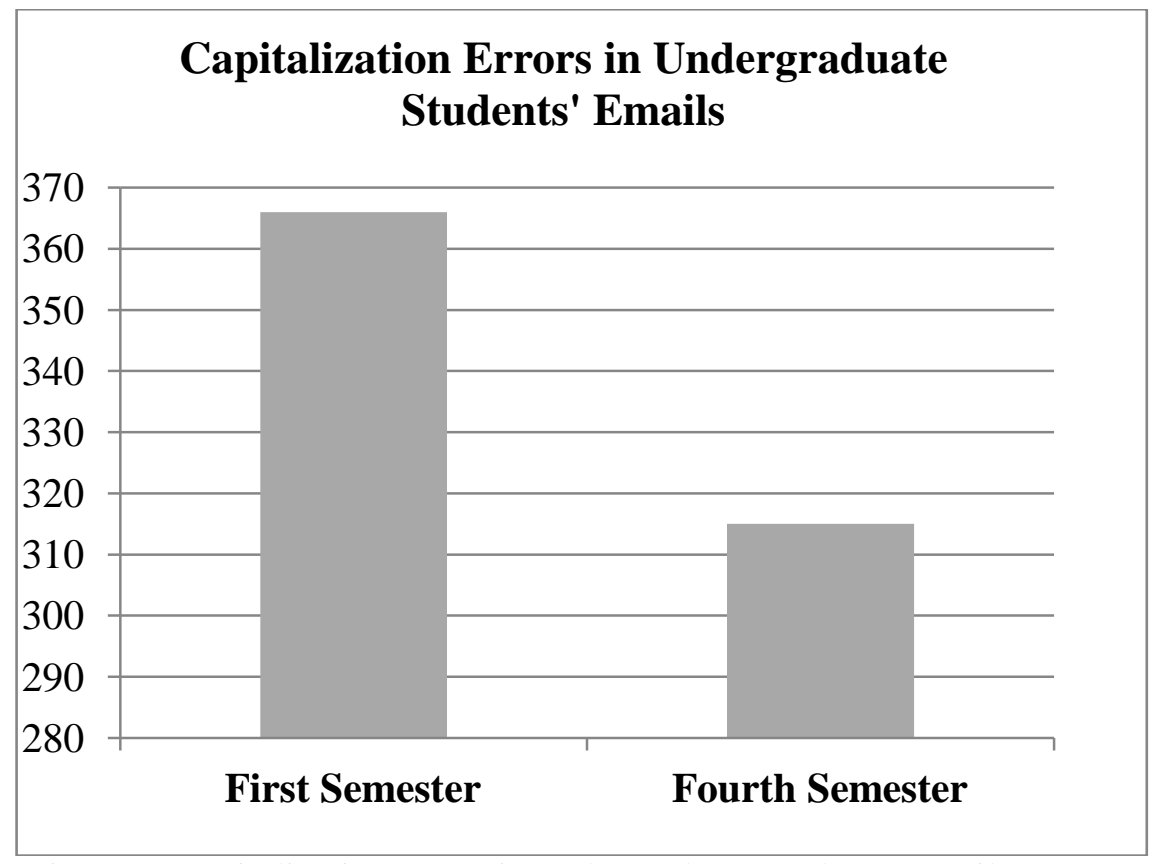

Figure 1. Capitalization errors in undergraduate students’ emails

\section{Textual Examples for Capitalization Errors}

In the absolute beginning of the email, one first semester student wrote "respected sir," which is an incorrect way of beginning a sentence 
in English language. The student needed to begin with a capital ' $r$ '. Thus, the statement should have been "Respected sir,"

Coming to another email, a fourth semester student wrote after a full stop "is it of enough length or not?" In this sentence, the student needed to use the first letter as capital because it was beginning after a full stop. Thus, the sentence should have been "Is it of enough length or not?"

\section{Word Order Errors}

The word order basically means an accurate arrangement of the words in a grammatical sequence of the language. When this syntactic sequence is not followed, then it becomes the Word Order error. In the emails, the first semester students executed this error 15 times, while the fourth semester students did it 9 times. The graphical figure compares their frequencies as follows:

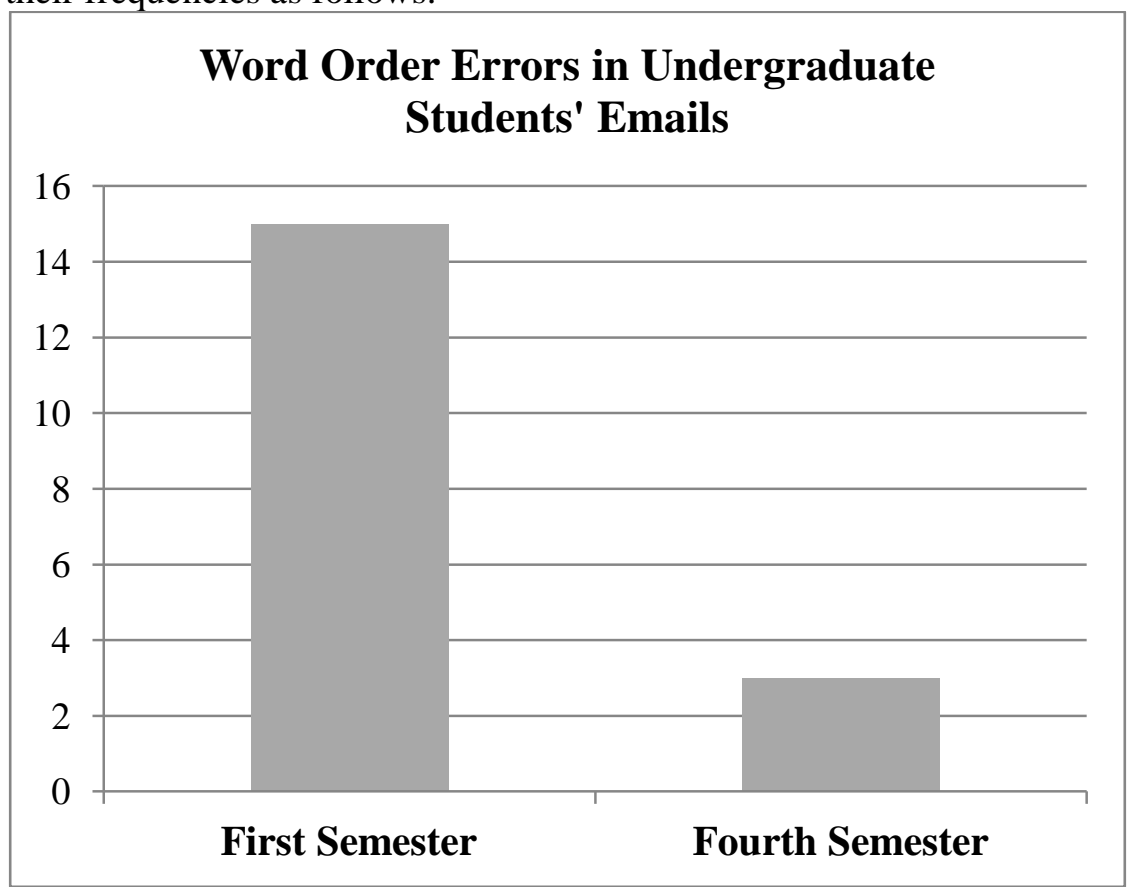

Figure 2. Word order errors in undergraduate students’ emails

\section{Textual Examples for Word Order Errors}

A student of first semester, in an email, wrote a statement: “...that is why today I submitted..." which contains an incorrect syntactic 
arrangement. It should have been written like this: "that is why I submitted it today.”

One student of fourth semester wrote in his email: “...but confusing above question." This statement needed to be written as: "...but above question was confusing."

\section{Subject-verb Agreement Errors}

One of the significant rules of English grammar is that the subject of the sentence should be in agreement with the form of the verb. This implies that if the subject is singular, then the verb must also be in the apt form, accordingly. For instance, one cannot say "We was there" rather, it has to be written as "We were there" to show the subject-verb agreement. If this pattern/rule is not followed, then it is classified as the subject-verb agreement error. Within the given data, the first semester students committed the subject-verb agreement error 10 times while the fourth semester students did the error 6 times. The graphical representation is as follows:

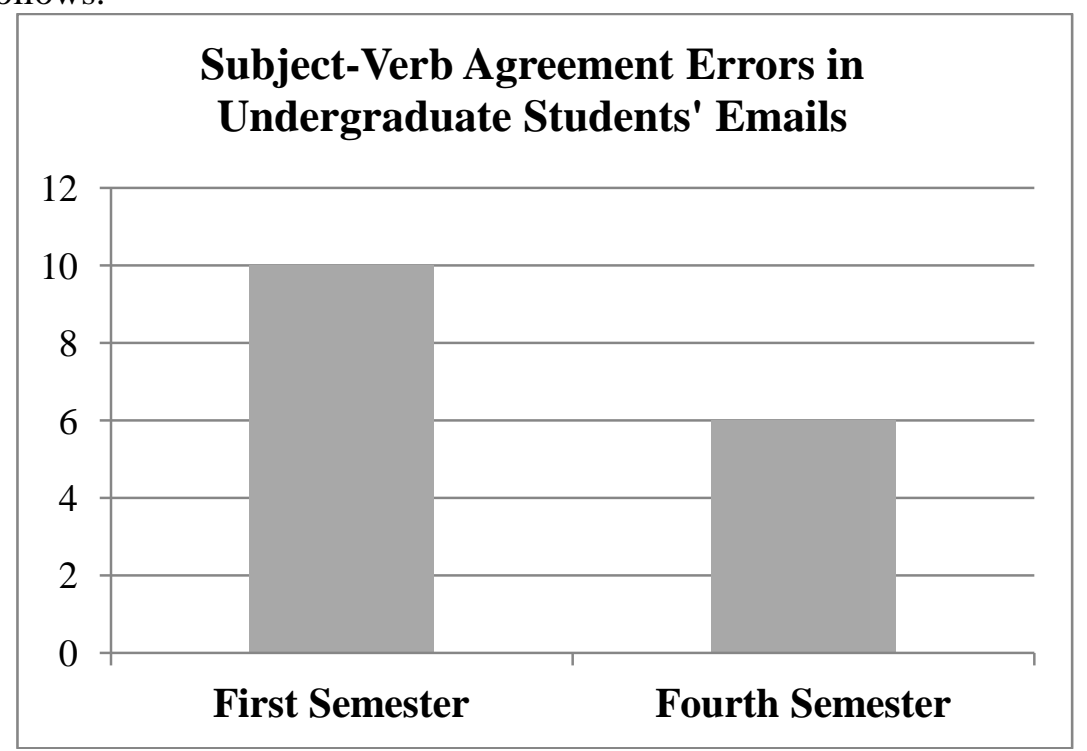

Figure 3. Subject-verb agreement errors in undergraduate students' emails 


\section{Textual Examples for Subject-verb Agreement Errors}

One student belonging to the first semester wrote: “...exams has not been started yet." This is an incorrect statement syntactically because there is no subject-verb agreement within it. It should have been like this: “...exams have not been started yet” in order for it to be acceptable as correct.

A student belonging to the fourth semester wrote in her email: “...I discuss different aspects of the narrator's personality." This is an incorrect statement because the verb's form has not been used in agreement with the subject and the context of the statement. It should have been written as "I have discussed different aspects of the narrator's personality" or it could have been written as "I will discuss different aspects of the narrator's personality.”

\section{Pronoun Errors}

The pronoun is the word that comes in the place of a noun, referring to that noun. The pronoun is used to avoid constant repetition of the name of the noun again and again. There are multiple types of pronouns and there are certain grammatical rules for them as well. One particular pronoun is to be used for a specific noun only. One cannot use one pronoun for all kinds of nouns that is why the writer has to be careful while employing pronouns. When a learner is unable to use these pronouns appropriately then the errors are classified as pronoun errors. These errors were committed 18 times by the first semester students. Meanwhile, they were done only 10 times by the fourth semester students in the emails. The graphical representation of the findings for this category is as follows: 


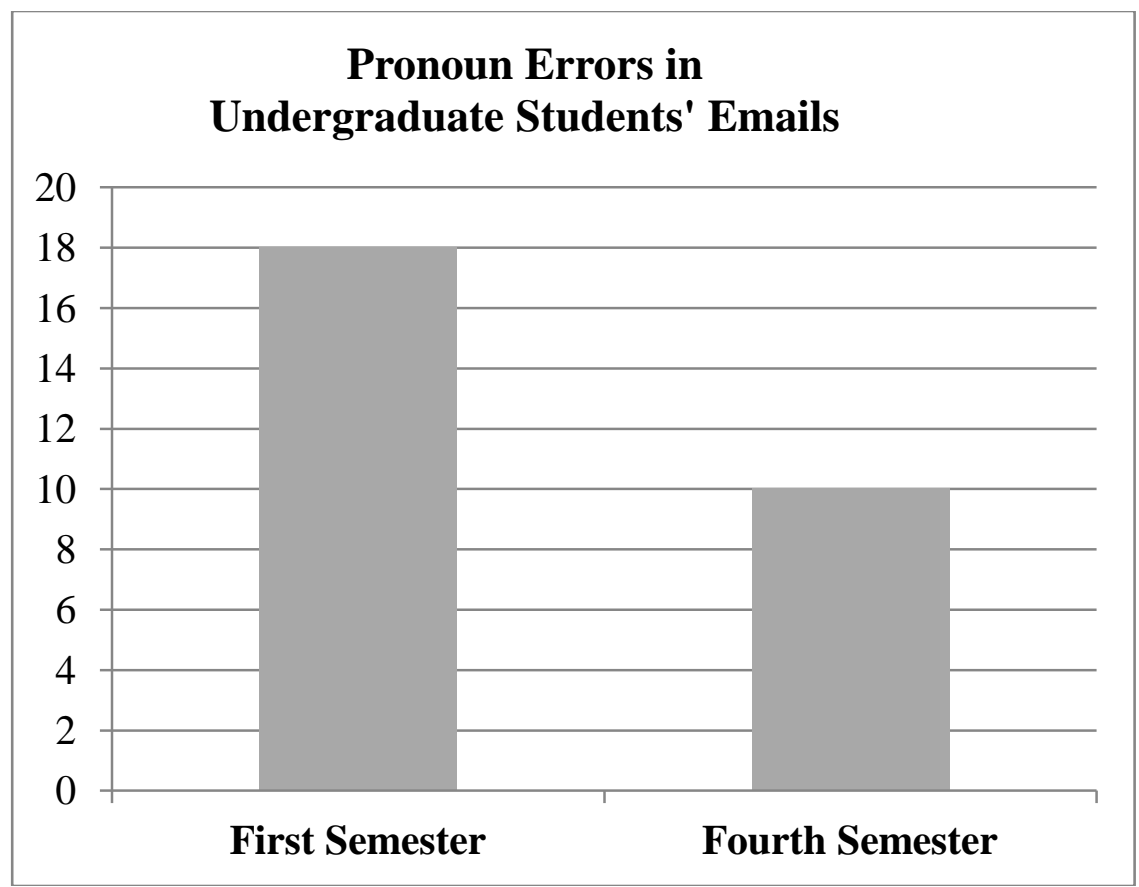

Figure 4. Pronoun errors in undergraduate students’ emails

\section{Textual Examples for Pronoun Errors}

From the first semester, a student wrote in his email: "I want to confirm about the date or time of the second sessional exams, today is 17 November and exams have not started yet." In this sentence, the student did not need to mention the noun of 'exams' again. Instead, he could have said "...they have not started yet" to make it more grammatically appropriate and correct.

A fourth semester student jotted down: "but I have not received any mail from any of my group members so I was waiting for my group members." Here the student repeated the noun phrase of 'my group members' unnecessarily. He should have used the word 'them' instead.

\section{Spelling Errors}

The errors which are committed when appropriate spellings for a particular word, are not used by the learner in his/her writing are called as the spelling errors. Using accurate spellings is essential to convey the right message to the receiver. If proper spellings are not used, then the 
particular message might be misunderstood as well. The first semester students executed this error 276 times in their emails. On the other hand, the fourth semester students did it 171 times. The graph representing the frequencies is displayed below:

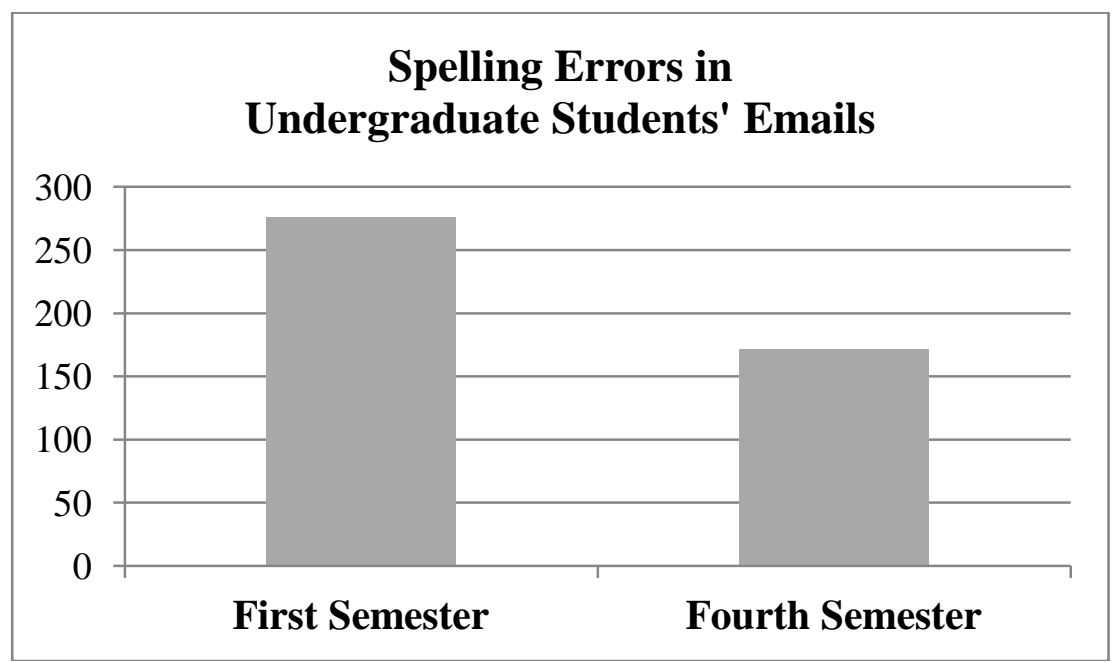

Figure 5. Spelling errors in undergraduate students' emails

\section{Textual Examples for Spelling Errors}

A student of first semester wrote in his email: "I will be very thankful to you." This statement contains incorrect spellings for the word 'thankful' and that is why it was categorized under the heading of Spelling Errors.

From the fourth semester, a student wrote "they have dispatched the study material on $20^{\text {th }}$ of September..." This sentence comprises of inaccurate spellings of the word 'dispatched'.

\section{Verb Tense Errors}

One common kind of error found among second language learners is the incorrect use of Verb Tense. The tenses basically convey the accurate time of that action within the context of the statement. They tell immediately that whether the action has been done in the past or present or the future. This helps sort out many confusions while delivering a message to the receiver. However, when the verb tense is not correctly employed within a sentence, then it contains the risk of delivering a 
wrong message as well. Students of first semester employed this error of verb tense 111 times in their emails, while the fourth semester students executed it 72 times. The graph for this section is below:

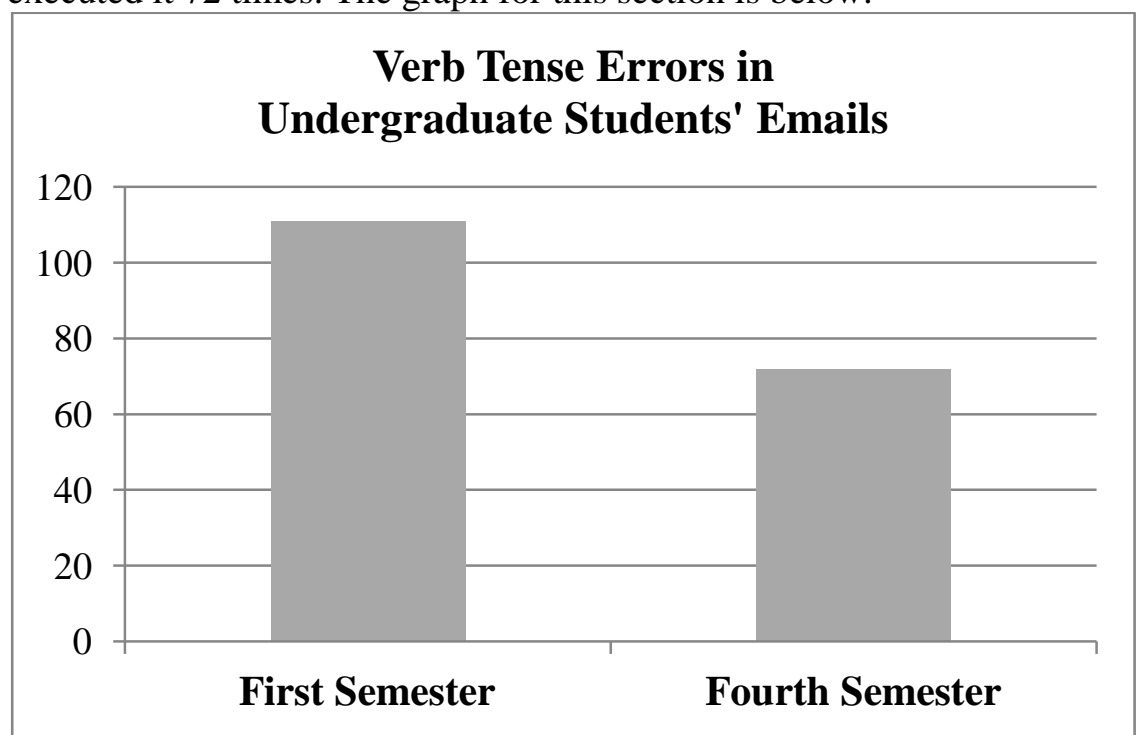

Figure 6. Verb tense errors in undergraduate emails

\section{Textual Examples for Verb Tense Errors}

A student of first semester wrote in his email: "I received and attempt assignments, GDBs and Quizzes of all courses.” this sentence contains an error of verb tense. The verb 'attempt' should be written as 'attempted' as per the context of the statement.

One student of fourth semester wrote in her email: "The cursor of mouse become out of control.” This statement exhibits a mistake in the verb tense area. The word 'become' should have been 'became' as they student was narrating an issue that had already happened with her in the past.

\section{Preposition Errors}

A preposition basically shows the physical position of a noun or a pronoun. It also helps to relate the noun with other lexical items within a statement. Incorrect incorporation of a preposition can change the entire meaning of the statement very easily. In this category, the first semester students employed this error 27 times in their writings while the fourth 
semester students committed it 20 times. The graph for comparison is as follows:

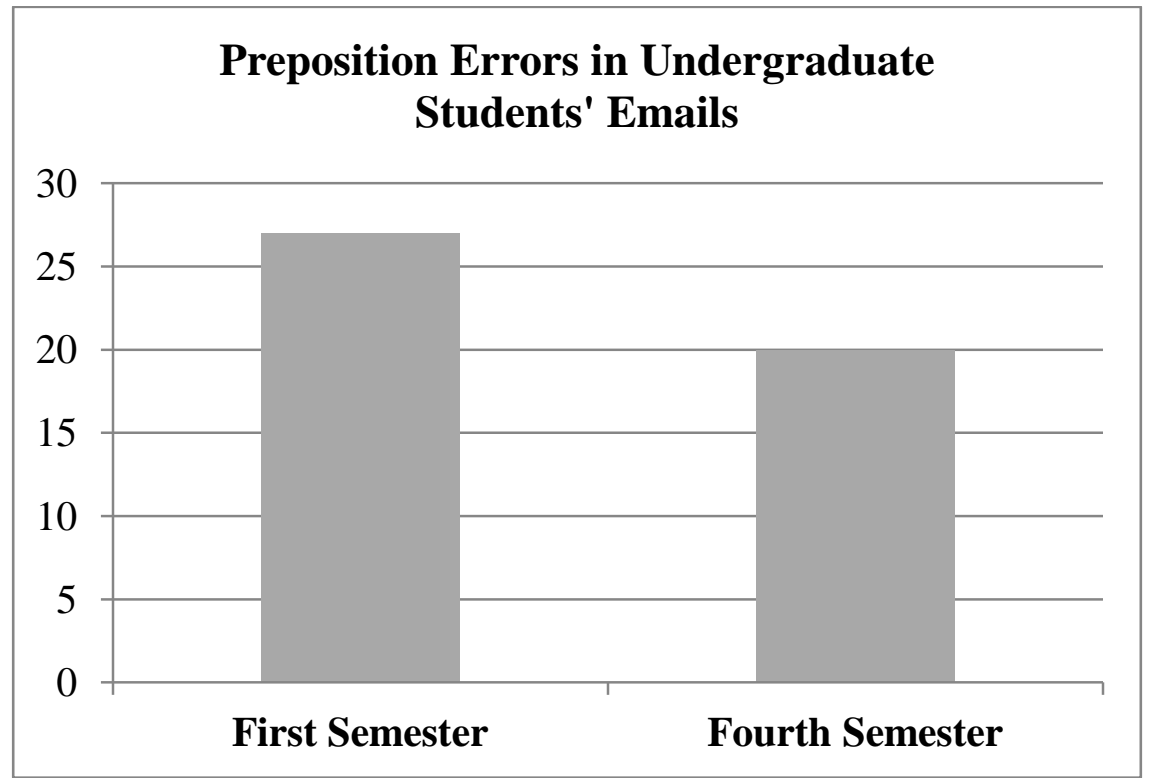

Figure 7. Preposition errors in undergraduate students' emails

\section{Textual Examples for Preposition Errors}

A first semester student jotted down in his email: "I was at leave at home". This was an incorrect use of the preposition 'at'. He should have stated it as this: "I was on leave, at home" to make it sound more correct.

One student belonging to the fourth semester wrote in her email: "I suffered in this disease", which is again an incorrect usage of the preposition 'in'. She should have written this statement as this: "I suffered from this disease."

\section{Article Errors}

The article indicates the type of reference that is being made towards a noun in a sentence. English language has a total of three articles: a, an and the. They have varied use according to the context. A learner of English language needs to have an awareness of how to use the articles appropriately. The first semester students committed errors in using the articles 29 times, while the fourth semester students did these errors 15 times only. The graph for this category is as follows: 


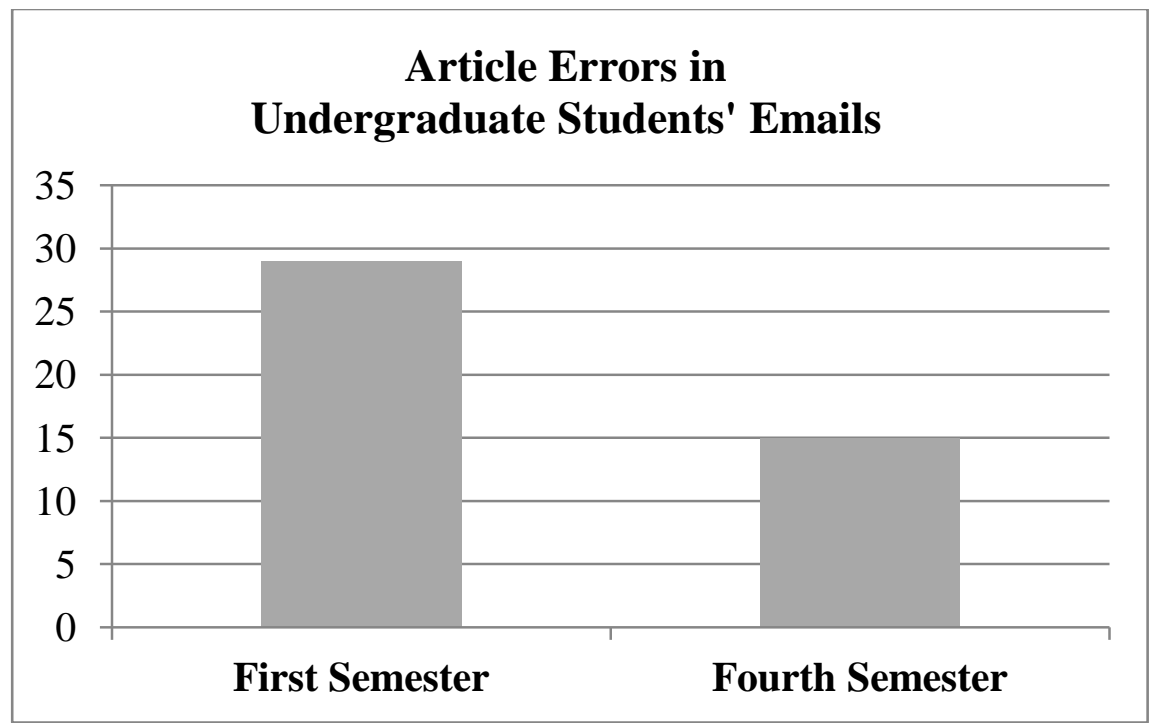

Figure 8. Article errors in undergraduate students' emails

\section{Textual Examples for Article Errors}

A first semester student wrote in his email: "How should I take the start of an essay which you have to us in picture?” This statement contains two article errors. Firstly, the student was talking about a specific essay so he should have used the article 'the' instead of 'an' with the word essay in the statement. Secondly, he was referring to a specific picture which the teacher had sent him to write an essay on, therefore, he should have used the article 'the' before the word 'picture' in the statement.

One student belonging to the fourth semester wrote to her teacher: "Madam I will try my level best to complete quiz in the remaining time". This statement contains an article error. The student should have used the article 'the' before the word 'quiz' in the statement because she was referring to a particular quiz of her semester.

\section{Punctuation Errors}

The punctuations are very essential in English language. Inappropriate or no use of punctuation can give an entirely different message to receiver from the sender. A clear knowledge of punctuation is essential for every person who writes in English language. The first semester students committed this error 129 times, while the fourth semester students did this error 60 times. The graphical figure for the findings of this sub-section has been presented as follows: 


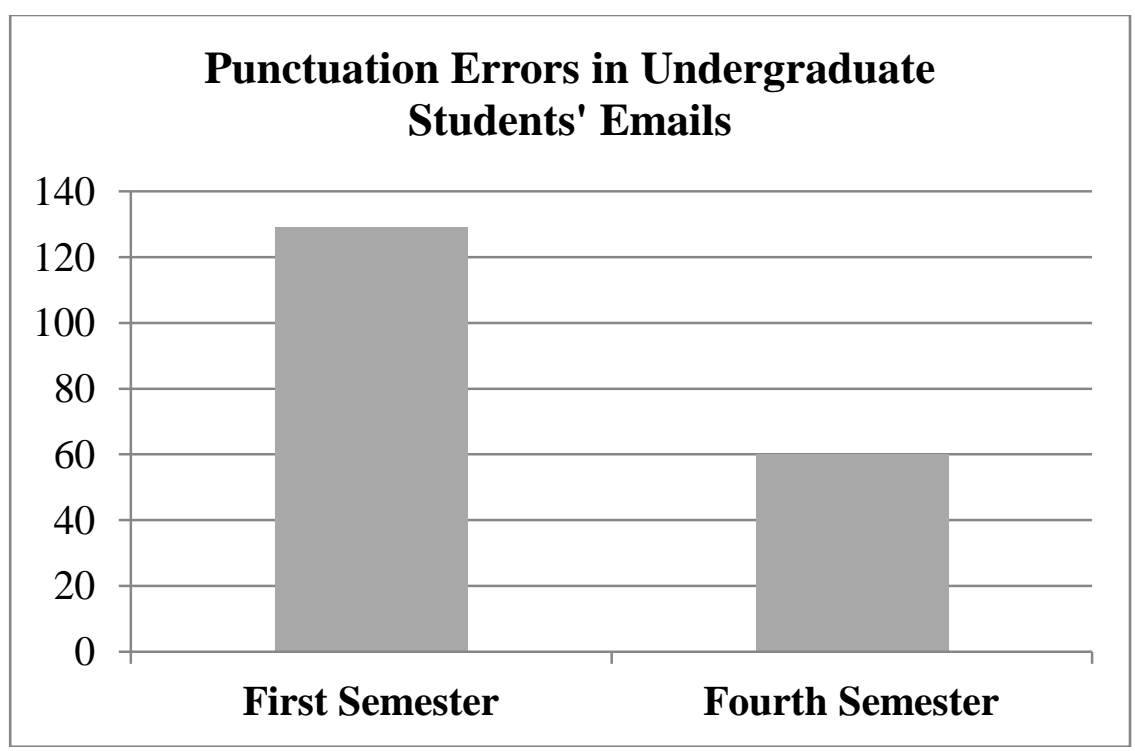

Figure 9. Punctuation errors in undergraduate students’ emails

\section{Textual Examples for Punctuation Errors}

A first semester student wrote in his email to his teacher: "Can I email the assignment to you please???” The purpose of the question mark is to convey the idea to the reader that this statement is an interrogative one. However, three question marks were not needed and thus, they classify it as an error in use of this punctuation mark.

One of the students belonging to the fourth semester jotted down in his email: "Can you guide me which is not a type of validity." Here the student should have used the question mark '?' instead of a full stop '.'

\section{Sources of Errors in Selected Emails: An Insight}

Applying Richards' (1971) framework upon the collected data enabled the researcher to reveal insightful understanding regarding the origin of the errors. In accordance with the aforementioned study, there are mainly two basic types of sources of errors among the ESL learners: (1) Inter-lingual and (2) Intra-lingual. Here, the former category refers to those errors which are observed containing norms of one language (or 
first language) while writing another language (usually the second language). Furthermore, the latter category denotes those errors where the learner displays a failure to acquire the correct rules of the target language.

Using scholarly insights of previous researchers, the current study attempted to explore the origination of errors within the students' emails as well. This revealed that the first semester students engaged in more inter-lingual errors (60\%) than the intra-lingual errors (40\%) within their email communication with their teachers. Contrastingly, the fourth semester students committed more intra-lingual errors (53\%) than the inter-lingual errors (46\%). This outcome explains the notion that these Pakistani students initially incorporate the rules of their first language (Urdu) while using their target language (English). However, by the time they reach their fourth semester, they tend to develop a distinction between their first language and second language, and then, tend to make errors which are directly related with the particular language (English) they are using while writing an email. The findings have been graphically presented below:

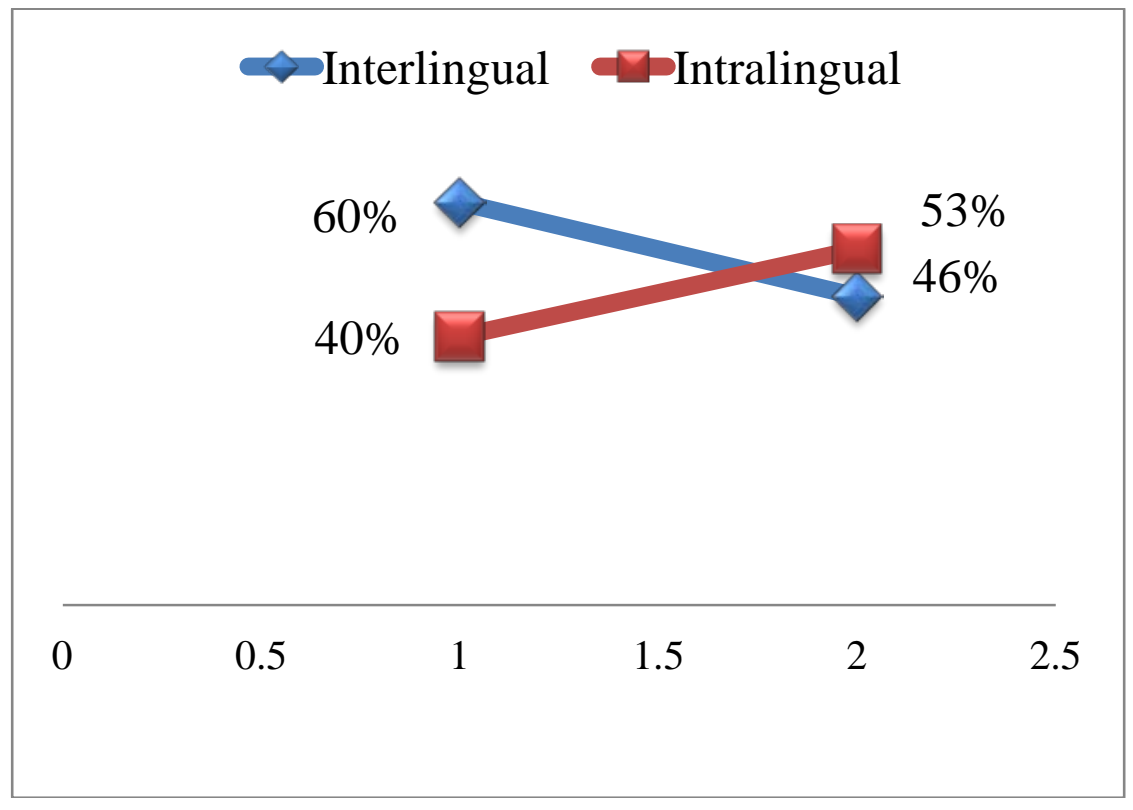

Figure 10. Comparison of sources of errors 


\section{Inter-lingual Errors: Textual Examples}

First semester students extensively employed inter-lingual errors within their electronic communication with teachers (60\%). The analysis of their emails brought a further variety within this category. For instance, a first semester student wrote "I try to write about topic assigned by aap." Here, he employs two irregularities. Firstly, he uses the present tense in the form 'try', whereas he should have used 'tried'. This discrepancy is a result of first language interference because the student first formulated a sentence in his native tongue (which is Urdu here) and then literally translated it. In Urdu, one does not add suffixes with the main verb to indicate the past tense, it remains the same. Whereas, in English language, the addition of '-ed' is a necessity. Thus, here, he follows the structure of his first language and this causes an interference resulting in an inter-lingual error. Secondly, in the same sentence, he directly incorporates a word of Urdu ('aap' means 'you' in English) and writes it in the English script. This is another obvious intrusion of the first language within the electronic communiqué. Further insightful examples (inter-lingual errors have been underlined) include the following:

- "I want to confirm about the date or time of second Sessional exams." (direct incorporation of the Urdu word 'aur' / 'or' which means 'and' in English)

- "Please send me through email." (direct translation of the Urdu structure, which changes the implied meaning when transformed into English)

- “...but we did not get." (direct translation from Urdu language, which becomes an incompletely closed sentence when transformed into English)

Another interesting finding, within the data, was the ignorance of capitalization by majority of first semester students. For instance, "i’ll be very thankful”, "regards, ifra naz", "i could not prepare” etc. This discrepancy echoes Urdu's norms as it does not demand capitalization unlike English. And, thus, the students tend to ignore it consistently in their emails too. 


\section{Intra-lingual Errors: Textual Examples}

The students belonging to fourth semester majorly committed intralingual errors (53\%) and the analysis of their email communication brought insightful findings. For instance, a student wrote in his email: "...will be more carefull in future." Here, the learner understood the phonological sound of the word 'careful' and considered the word to be a compound of the words 'care' and 'full'. Thus, he generalized 'full' to be a part of this word and did not write the correct spellings. A similar discrepancy can be found within the following instances: “...according to my knowledge as I red in lecture 14...", "I have done almost the question...", “...really very thankfull to you”, "we'll be greatful to you." Such errors are caused by incomplete knowledge of the learner and not by the intervention of the first language, and hence, they are termed as intra-lingual errors based on the investigation of their origin.

Furthermore, Pakistani students often use internet slang within their formal emails, considering them to be a norm of the communication done on the internet. For instance, fourth semester students wrote "urs obediently...", "can u accept my assignment...”, "plz help me out”, "my first quiz was so gud", "pls madam see the attached file." In addition, some students incorporate informal contractions within their emails to their teachers as well. For example, "I'm gonna work." Such discrepancies reveal that the learners have not properly comprehended the distinction between formal and informal, and standard and nonstandard style of writing.

Additionally, learners tend to generalize the basic rules for tenses on all of their statements which generate intra-lingual errors. For instance, a student wrote: "if you received my assignment then please marked it". Here, he uses the word 'received' correctly, however, he generalizes the same past tense rule to the next phrase which, being a request to the teacher, was supposed to be in simple present tense (i.e. 'please mark it'). Such insights reveal that the learners tend to formulate certain hypothesis regarding the target language and then use it while communicating in it.

\section{Discussion on Overall Results}

The analysis conveys the fact that the first semester students commit errors frequently than the fourth semester students. One reason for this reduction can be their longer learning experience in the MA English Program. After assessment of the overall assessed frequencies of errors, it has been observed that the majority of the errors committed by the 
students from both semesters were of capitalization. All the frequencies have been graphically represented as follows:

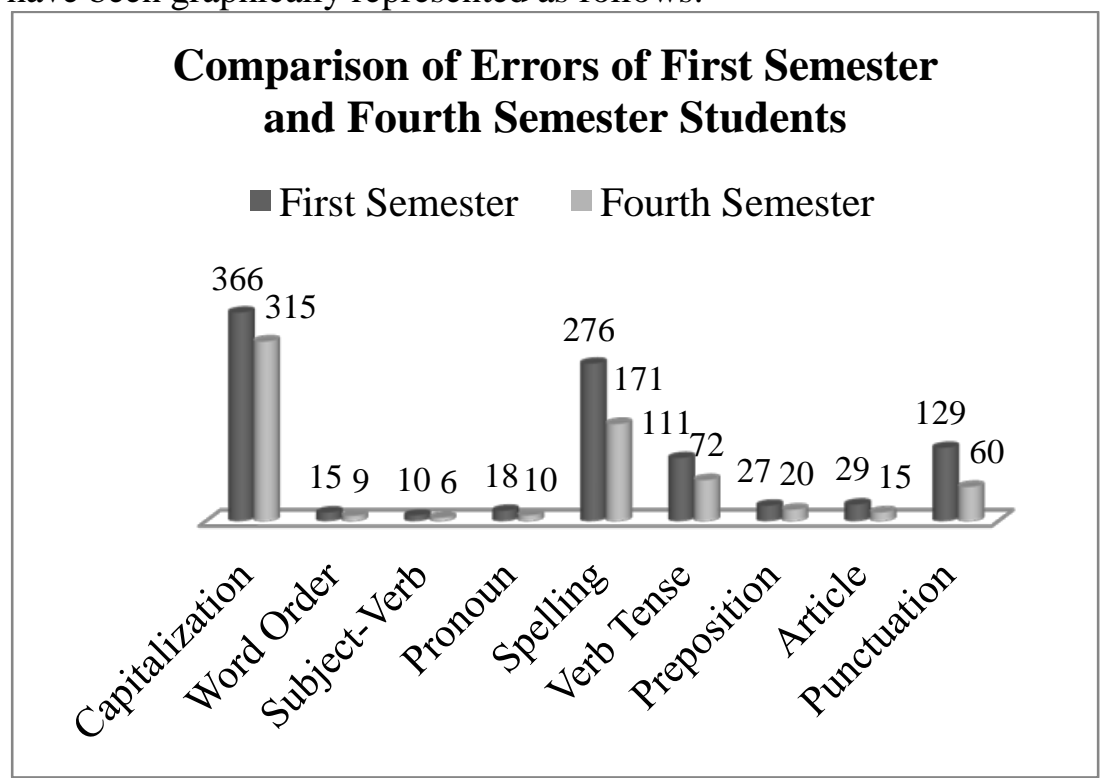

Figure 11. Comparison of errors of first semester and fourth semester students

The category in which least errors were committed by both classes was the category of Subject-Verb Agreement Errors. The categories of Capitalization, Spelling, Punctuation and Verb Tense received the most errors from both semesters. These fields need particular attention from the teachers so that the students minimize their errors in the future.

\section{Errors Committed by First Semester Students: A Bird's Eye View}

The frequencies received after the conduction of analysis were converted into percentages in order to give a holistic view about the errors committed by the first semester students individually. This analysis will be helpful in assessing particularly this class of MA English. It will enable their teachers to focus more on the most frequently occurring errors more and will help the students to lessen their errors while writing and communicating in English language. The overall percentage of each type of error committed by the first semester students has been graphically represented in the form of a pie chart as follows: 


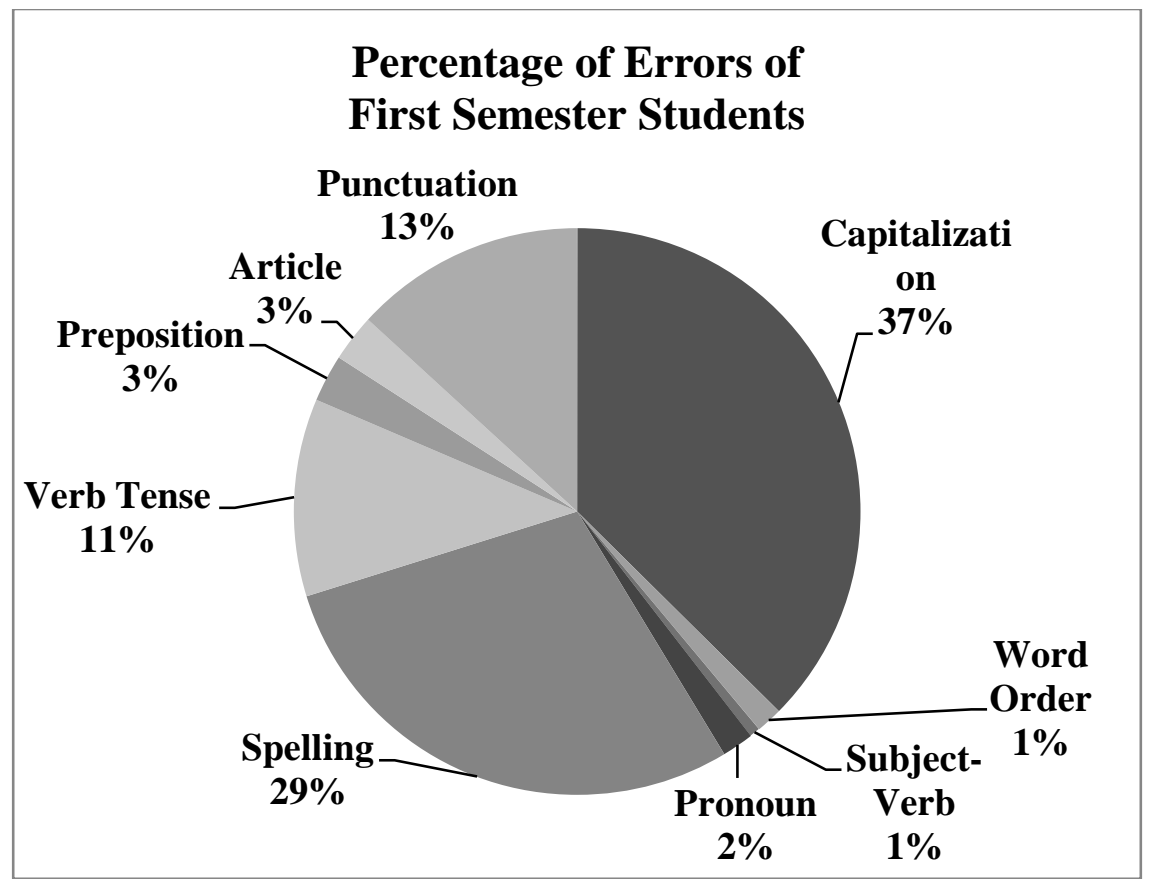

Figure 12. Percentage of errors of first semester students

The above given graph conveys that the Capitalization errors constitute $37 \%$ of the total errors committed by the First Semester Students, while the Spelling errors take $29 \%$ and the Punctuation errors take $13 \%$ of the space. After them, the Verb Tense errors come, which take $11 \%$ space of the total errors of First Semester Students' errors. After this category, come the lesser prominent categories including: Article Errors (3\%), Preposition Errors (3\%), Pronoun Errors (2\%), Word Order Errors (1\%) and Subject-Verb Agreement Errors (1\%).

\section{Errors Committed by Fourth Semester Students: A Bird's Eye View}

The percentage of each category of errors, committed by the fourth semester students, has been graphically represented in the form of this pie chart below: 


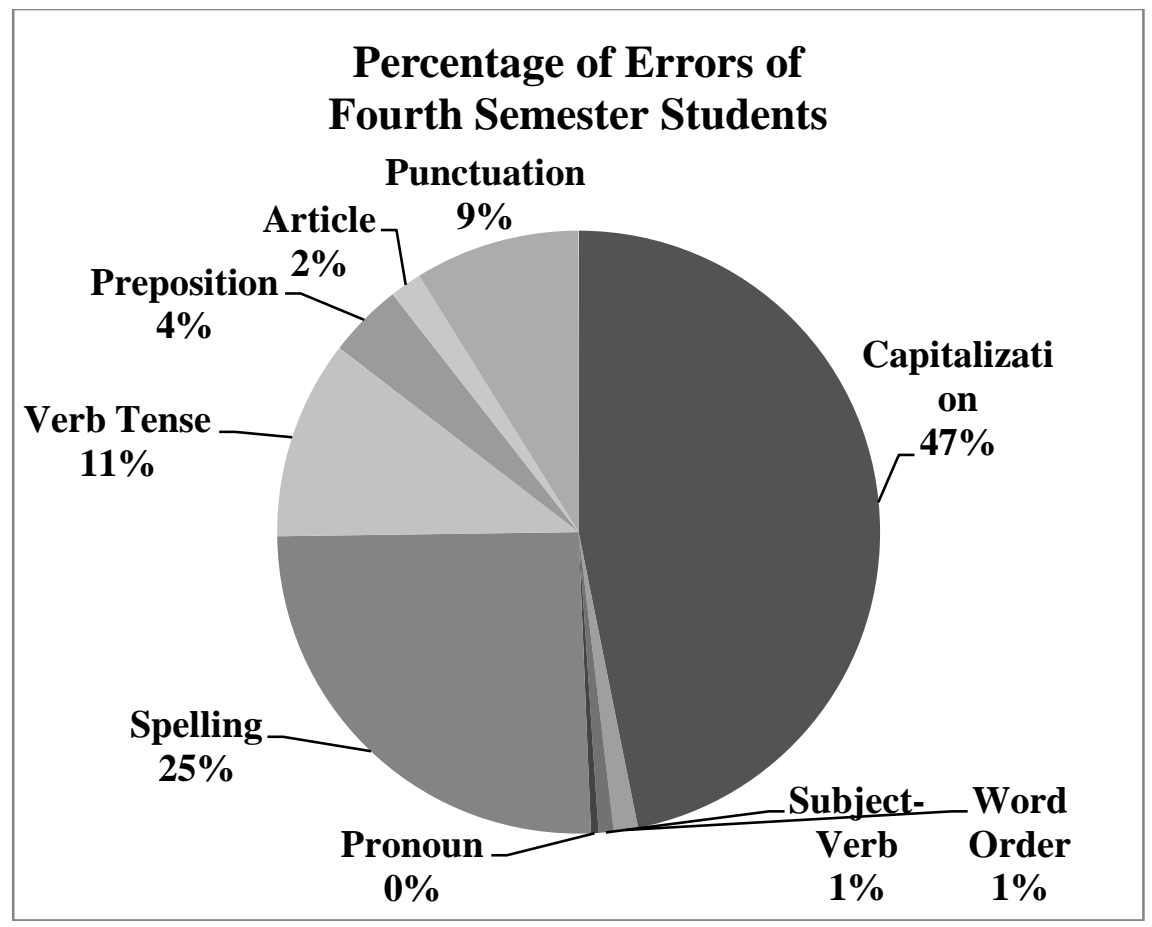

Figure 13. Percentage of errors of fourth semester students

The above given graph conveys that the Capitalization errors constitute $47 \%$ of the total errors committed by the Fourth Semester Students, while the Spelling errors take $25 \%$ and the Verb Tense errors take $11 \%$ of the space. After them, the Punctuation errors come, which take 9\% space of the total errors of First Semester Students' errors. After this category, come the lesser prominent categories including: Preposition Errors (4\%), Article Errors (2\%), Subject-Verb Agreement Errors (1\%), Word Order Errors (1\%) and Pronoun Errors (0\% i.e. almost negligible).

\section{Conclusion}

In recent years, there have been a growing number of studies in the area of Error Analysis. The main aim of the studies was to recognize and classify the errors and aid teachers to know problems of ESL learners to help them learn in better way. Based on the research work which has been performed in the area of EA, it is clear that this methodology significantly helps in realizing the learners' errors. In connection to the 
significance of second language learners' errors both in learning and teaching, TEFL educators and researchers should regularly conduct such an Error Analysis based research in order to adopt appropriate teaching strategies to help ESL students learn better.

The current study aimed to explore, identify and describe the errors committed by students belonging to first and fourth semester students of MA English (Undergraduate) program at COMSATS Institute of Information Technology. The findings of research convey that the Capitalization errors were the most frequently occurring in both the semester students' emails. After Capitalization, their Spelling errors, Punctuation errors and Verb tense errors occurred most frequently in their written emails. Moreover, the first semester students' language errors involved frequent interference of the first language (Urdu). While, the second semester students' errors depicted an incomplete knowledge of the target language (English).

\section{Recommendations}

From the 1950s, there has been a growing concern regarding errors conducted by ESL learners and these errors have been considered as a primary barrier to their understanding and communication. Studies established that interference of first language system causes these discrepancies initially, and if remain uncorrected, they become a habitual part of the ESL learner. Hence, EA came to the aid for addressing various such linguistic errors separately and for establishing their origin. This methodology aims at removing the error from its root cause and hence, can prove to be fruitful for the language teachers. Furthermore, such insights can be incorporated by the teachers in their classroom lectures and also in their corrective feedback for helping the students develop an awareness regarding their language-based errors.

The analysis tells us that there are four major fields on which the teachers of these students need to focus the most. Firstly, the language teachers need to enhance the understanding of their students in Capitalization. The students need to know where they should use ' $i$ ' in the form 'I' and where it will be written in the form ' $i$ '. Secondly, they need to make particular efforts to make the students acquire the correct spellings for every word which they use. Thirdly, the language teachers should particularly teach the use of each and every punctuation mark of English language along with practical exercises, so that they incorporate that knowledge in their day to day writings as well, like Emails. Lastly, the learners need to be told about their verb tense errors in detail as well. So that, they make use of the appropriate tense to convey the appropriate time as per the context of the statement they are using. 
This study also aims to bring awareness of the necessity of such studies to be conducted at every pedagogical institute. It will help bringing the weak areas of the students into limelight and will help the teachers brainstorm and plan their language classes with the specific goal of improving their students.

\section{References}

AbiSamra, Nada. (2003). An Analysis of Errors in Arabic Speakers English Writings. Retrieved on December 12, 2014 at 12:14 from http://abisamra03.tripod.com/nada/languageacqerroranalysis.html

Adas, D., \& Bakir, A. (2013). Writing Difficulties and New Solutions: Blended Learning as an Approach to Improve Writing Abilities. International Journal of Humanities and Social Science, 3 (9), 254-266.

Albert, M. L. \& Obler, L.K. (1978). The Bilingual Brain: Neuropsychological and Neurolinguistic Aspects of Bilingualism. New York: Academic Press.

Alhaisoni, M. (2012). An Analysis of Article Errors among Saudi Female EFL Students: A Case Study. Asian Social Science Canadian Center of Science and Education, 8(12), 55-66.

Beebe, L.M. (1988). Issues in Second Language Acquisition: Multiple Perspectives. London: Newbury.

Brown, D. (1994). Principles of Language Learning and Teaching. New Jersey: Prentice Hall Regents.

Bums, N. \& Grove, S. K. (1997). Introduction to qualitative research. In N. Bums, \& S. K. Grove, (Eds.). The practice of nursing research: Conduct, critique, \& utilization (3rd ed.) (pp. 67-90). Philadelphia, PA: W. B. Saunders Company.

Burt, M., \& Kiparsky, C. (1978). Global and local mistakes, in J. Schumann \& N. Stenson (Eds.). New frontiers in second language learning. Rowley, Massachusetts: Newbury House Publishing, Inc.

Cole, J., \&, Feng, J. (2015). Effective Strategies for Improving Writing Skills of Elementary English Language Learners. Chinese American Educational Research and Development Association Annual Conference.

Carroll, J.B. (1964). Language and Thought. Englewood Cliffs: Prentice Hall. 
Corder, S.P. (1976). The Significance of Learner's Errors. 1RAL, 5, 161-170.

Corder, S. P. (1981). Error analysis and interlanguage. Oxford: Oxford University Press.

Crystal, D. (2003). English as a Global Language. Cambridge: Cambridge University Press.

Dechert, H.W. (1983). How a story is done in a second language. In C. Faerch, \& G., Kasper (Eds.). Strategies in Interlanguage Communication. London: Longman.

Doughty, C.J., \& Long, M.H. (2003). The Handbook of Second Language Acquisition. U.S.A: Black Well Publishing.

Dulay, H., Burt, M. \& Krashen, S. (1982). Language Two. New York: Oxford University Press.

Ellis, R. (1997). Second Language Acquisition. Oxford: Oxford University Press.

Fang, X., \&, Xue-mei, J. (2007). Error Analysis and the EFL Classroom Teaching. US-China Education Review, 4 (9), 10-14.

Hasyim, S. (2002). Error Analysis in the Teaching of English. Jurusan Sastra Inggris, Fakultas Sastra, Universitas Kristen Petra, 4(1), 42-50.

Intel. (2012). The Positive Impact of E-Learning. Retrieved on December 5, 2014 at 13:04 from http://www.intel.com/content/dam/ www/public/us/en/ documents/ white-papers/world-ahead-positiveimpact-of-elearning-paper.pdf

Jabeen, A., Kazemian, B., \&, Mustafai, M. S. (2015). The Role of Error Analysis in Teaching and Learning of Second and Foreign Language. Education and Linguistics Research, 1 (2), 52-61.

Jie, X. (2008). Error Theories and Second Language Acquisition. USChina Foreign Language, 6, 35-42.

JISC. (2004). Effective Practice with E-Learning. Retrieved on December 2, 2014 at 17:03 from http://www.jisc.ac.uk/media/ documents/publications/ effectivepracticeelearning.pdf

Keshavarz, M. D. (1999). Contrastive Analysis and Error Analysis (6 ${ }^{\text {th }}$ ed.). Tehran: Rahnama Press 
Khansir, A. A. (2012). Error Analysis and Second Language Acquisition. Theory and Practice in Language Studies, 2(5), 1027-1032.

Krashen, S. D. (1981). Second Language Acquisition and Second Language Learning. Retrieved on November 25, 2014 at 15:30 from http://www.sdkrashen.com/content/books/sl_acquisition_and_learnin g.pdf

Larson-Freeman, D. \& Long, M.H. (1991). An Introduction to Second Language Acquisition Research. New York: Longman.

Lee, E. P. (2001). Error Analysis on medical students' writing. Retrieved on October 21, 2014 at 15:16 from http://www.stc.arts.chula.ac.th/ ITUA/Papers_for_ITUA_Proceedings/Eunpyo-new.pdf.

Lott, D. (1983). Analysing and counteracting interference errors, ELT Journal, 37(3), 256- 261.

Maree, K., Creswell, J. W., Ebersohn, L., Eloff, I., Ferreira, R., Ivankova, N. V., Jansen, J. D., Niewenhuis, J., Pietersen, J., Plano Clark, V. L., \& Van der Westhuizen, C. (2007). First Steps in Research. Pretoria: Van Schaik Publishers.

Michaelides, N.N. (1990). Error Analysis: An Aid to teaching. English Teaching Forum, 38 (4), 28-30.

Mungungu, S. S. (2010). Error Analysis: Investigating the Writing of ESL Namibian Learners (Unpublished Masters' Thesis). University of South Africa, South Africa.

Nordquist, R. (2013). Mother Tongue. Retrieved on December 1, 2014 at 12:15 from http://grammar.about.com/od/mo/g/mothertongueterm.htm

Nzama, M. V. (2010). Error Analysis: A Study of Errors Committed by IsiZulu Speaking Learners of English in Selected Schools (Unpublished Masters’ Thesis). University of Zululand, Zululand.

Odlin, T. (1989). Language Transfer: Cross-linguistic influence in language learning. New York: Cambridge University Press.

Polio, C. G. (1997). Measures of Linguistic Accuracy in Second Language Writing Research. Language Learning, 41 (1), 101-143.

Rahman, T. (1997). Language and Politics in Pakistan. Karachi: Oxford University Press. 
Richards, J. C. (1971). A non-contrastive approach to Enor Analysis. English Language Teaching Journal, 25, 204-219.

Richards. J.C., Plott, J., \& Platt H. (1996). Dictionary of Language Teaching and Applied Linguistics. London: Longman.

Robins, H. R. (2014). Language. Retrieved on December 12, 2014 at 14:16 from http://www.britannica.com/EBchecked/topic/329791/ language

Sawalmeh, M. H. M. (2013). Error Analysis of Written English Essays: The case of Students of the Preparatory Year Program in Saudi Arabia. English for Specific Purposes, 40(14), 1-17.

Seligar, H. (1988). Psycholinguistic Issues in Second Language Acquisition, in Issues in Second Language Acquisition: Multiple Perspectives, Beebe, L. M. (Ed.). London: Newbury.

Selinker, L. (1971). The psychologically relevant data of second language learning, in The Psychology of Second Language Learning, Pimsleur, P., \& Quinn, T. (Ed.). London: Cambridge University Press.

Selinker, L. (1972). Interlanguage. IRAL, 10(3), 209-223.

Skiba, R. (1997). Code Switching as a Countenance of Language Interference. Retrieved on October 30, 2014 at 14:13 from http://iteslj.org/Articles/Skiba-CodeSwitching.html

Tabatabaei, S. \& Bakhtiarband, M. (2014). Application of Dynamic Assessment in Second and Foreign Language. Language Teaching, 4(3), 53-66.

Ulijin, J., \& Strother, J. (1995). Communication in Business and Technology. Frankfurt: Lang.

Willcott, P.J. (1972). An Analysis of the Written English of Native Speakers of Arabic as found in American History (Unpublished Doctoral Dissertation). The University of Texas, Austin, U.S.A.

Received on: February 22, 2016

Revised on: May 21, 2016

Accepted on: June 01, 2016 